\title{
Good Faith and Sincere Co-operation
}

\author{
CHRISTOPHER MCCRUDDEN
}

\subsection{Introduction}

The Withdrawal Agreement (WA) has several common provisions which set out various obligations as to how the WA (and the Protocol as an integral part of the WA) is to be interpreted and applied. Among these are the duty of 'good faith' and the duty of 'sincere cooperation', which feature in Article 5 WA. This provides, in part, that the EU and the UK 'shall, in full mutual respect and good faith, assist each other in carrying out tasks which flow from this Agreement'. In addition, Article 5 provides that this obligation of good faith is without prejudice to the application of Union law pursuant to this Agreement, in particular the principle of sincere cooperation'.

\subsection{How to Approach the Interpretation of Article 5 WA?}

'Good faith' is a general principle of international law, ${ }^{1}$ including international trade law, ${ }^{2}$ and is explicitly included in Article 26 of the Vienna Convention on the Law of Treaties (VCLT). ${ }^{3}$ What appear to be somewhat equivalent concepts feature in other specifically European agreements. Article 4(3) of the Treaty on European Union (TEU) applies the duty of 'sincere cooperation' (sometimes referred to as the principle of 'loyalty') to member states and the EU in the application of the EU Treaties. ${ }^{4}$ Article 3 of the European Economic Area (EEA) Agreement applies what the Court of the European Free Trade Association (EFTA

1 Robert Kolb, Good Faith in International Law (Hart 2017).

2 Marion Panizzon, Good Faith in the Jurisprudence of the WTO: The Protection of Legitimate Expectations, Good Faith Interpretation and Fair Dispute Settlement (Hart 2006).

3 'Every treaty in force is binding upon the parties to it and must be performed by them in good faith.'

4 It states: 
Court) terms the duty of 'sincere cooperation' or 'loyalty' to the parties to that Agreement. ${ }^{5}$ The relevant provision in these two European agreements is drafted in very similar terms to Article $5 \mathrm{WA}^{6}{ }^{6}$ except that they do not use the term 'good faith' and Article 4(3) TEU includes the duty to 'facilitate the achievement of the Union's tasks', which neither Article 3 EEA nor Article 5 WA includes. In light of the fact that Article 5 WA thus contains an amalgam of both international law and EU law terms, how should it be interpreted? As more closely related to the international law usage or to EU legal understanding?

Although the matter is not without doubt, a plausible interpretation of Article 5 WA is that the reference to 'good faith' is a reference to the international law concept and should be interpreted as such, ${ }^{7}$ but that this is an additional requirement on the parties, over and above the other obligations in Article 5, which is to be interpreted in light of Union law. Thus, although Article 5 is entitled 'Good Faith', the term only appears in the first paragraph of that provision. The temptation to

\footnotetext{
Pursuant to the principle of sincere cooperation, the Union and the Member States shall, in full mutual respect, assist each other in carrying out tasks which flow from the Treaties.

The Member States shall take any appropriate measure, general or particular, to ensure fulfilment of the obligations arising out of the Treaties or resulting from the acts of the institutions of the Union.

The Member States shall facilitate the achievement of the Union's tasks and refrain from any measure which could jeopardise the attainment of the Union's objectives.
}

See further Marcus Klamert, The Principle of Loyalty in EU Law (Oxford University Press 2014) and John Temple Lang, 'The Principle of Sincere Cooperation, the Charter, and Digitalisation' in U Bernitz, X Groussot, J Paju and S de Vries (eds), General Principles of EU Law and the EU Legal Order (Wolters Kluwer 2020) 31.

5 'The Contracting Parties shall take all appropriate measures, whether general or particular, to ensure fulfilment of the obligations arising out of this Agreement. They shall abstain from any measure which could jeopardize the attainment of the objectives of this Agreement. Moreover, they shall facilitate cooperation within the framework of this Agreement.' See further John Temple Lang, 'The Principle of Sincere Cooperation in EEA Law' in Carl Baudenbacher (ed), The Fundamental Principles of EEA Law: EEA-ities (Springer 2017) 73; Páll Hreinsson, 'General Principles' in Carl Baudenbacher (ed), The Handbook of EEA Law (Springer 2016), 349.

6 'The Union and the United Kingdom shall, in full mutual respect and good faith, assist each other in carrying out tasks which flow from this Agreement. They shall take all appropriate measures, whether general or particular, to ensure fulfilment of the obligations arising from this Agreement and shall refrain from any measures which could jeopardise the attainment of the objectives of this Agreement.'

7 Where 'good faith' appears elsewhere in the WA (Arts 36(2), 159(3), 169(1), 175 and 184), this should be interpreted also according to international law. 
interpret the whole Article in light of this, applying an international law lens to the other provisions as well, should be resisted. This understanding draws strength from Article 4 WA. Article 4(4) provides that ' $[t]$ he provisions of this Agreement referring to Union law or to concepts or provisions thereof shall in their implementation and application be interpreted in conformity with the relevant case law of the Court of Justice of the European Union handed down before the end of the transition period'. With the exception of the 'good faith' provision, Article 5 is, therefore, to be interpreted in accordance with Court of Justice of the European Union (CJEU) case law. This interpretation is strengthened further by Article 4(1) WA which provides that ' $t$ ] he provisions of this Agreement ... shall produce in respect of and in the United Kingdom the same legal effects as those which they produce within the Union and its Member States'. It is clear that, with the exception of the 'good faith' provision, the remainder of Article 5 is likely to be interpreted in the Union and the member states along the lines of the case law on Article 4(3) TEU.

The matter is not free from doubt, however, given that Article 3 of the Trade and Cooperation Agreement (TCA), ${ }^{8}$ drafted in almost identical terms to Article $5 \mathrm{WA}$, is subject to Article 4 TCA, which states that the provisions of the TCA must be interpreted according to international law, and not according to EU law. ${ }^{9}$ This would seem to result in a conclusion that Article 3 TCA may give rise to different obligations on the parties than does Article 5 WA. While this appears to be counter-intuitive, this conclusion would accurately reflect the way in which the interpretation of these provisions is heavily context specific, a point we return to subsequently. In light of this, this chapter considers primarily how the meaning and scope of Article 5

${ }^{8}$ Which states:

1. The Parties shall, in full mutual respect and good faith, assist each other in carrying out tasks that flow from this Agreement and any supplementing agreement.

2. They shall take all appropriate measures, whether general or particular, to ensure the fulfilment of the obligations arising from this Agreement and from any supplementing agreement, and shall refrain from any measures which could jeopardise the attainment of the objectives of this Agreement or any supplementing agreement.

9 Art 4(2) TCA: 'For greater certainty, neither this Agreement nor any supplementing agreement establishes an obligation to interpret their provisions in accordance with the domestic law of either Party.' 
WA is clarified by examining the interpretation of the analogous concepts by the CJEU and the EFTA Court.

\subsection{Article 5 WA in Detail}

\subsection{1 'Objectives' of the WA and the Protocol}

Each of the Agreements mentioned so far refers to the 'objectives' of these Agreements and relates the concept of 'good faith' (or equivalent) to the delivery of these 'objectives'. The Agreements differ significantly in what they identify as their objectives and these differences need to be given sufficient weight when interpreting the obligations of the parties in Article 5 WA. Some of these objectives are considerably more ambitious than others. For example, Article 3 TEU, setting out the objectives of the Union, goes considerably further than Article 1 of the EEA Agreement, the objectives of which are simply '... to promote a continuous and balanced strengthening of trade and economic relations between the Contracting Parties with equal conditions of competition, and the respect of the same rules, with a view to creating a homogeneous European Economic Area.... In the EU context, but not in the EEA, the principle of 'sincere cooperation' has been understood as an expression of EU solidarity and a reflection of the principle of 'federal good faith', ${ }^{10}$ 'which is designed to secure mutual respect and readiness to co-operate with respect to the powers exercised by the legislative, executive and judicial bodies of different levels of authority within a "federal" system'.

So, too, the objective of the WA as a whole is stated in deceptively simple, and relatively restrained, terms in Article 1 WA: "This Agreement sets out the arrangements for the withdrawal of the United Kingdom of Great Britain and Northern Ireland ... from the European Union ....' The objective of the Protocol, on the other hand, is stated in more specific and wide-ranging terms: addressing the unique circumstances on the island of Ireland, maintaining the necessary conditions for continued North-South co-operation, avoiding a hard border and protecting the 1998 Agreement in all its dimensions. This means that the Protocol has, to an extent, 'Europeanised' the 1998 Agreement, meaning that upholding that Agreement has become an EU

${ }^{10}$ Koen Lenaerts and Piet Van Nuffel, Europees Recht (Intersentia 2011), quoted in Hreinsson (n 5) 357. See also Klamert (n 4) 47.

${ }^{11}$ Hreinsson (n 5) 357. 
objective in the context of the WA, and no longer simply a UK-Irish objective.

How these differences in ambition regarding objectives should lead to differences in the application of the obligations in Article 5 WA is likely to become a contested issue. All that can be said for the moment is that the greater the depth of integration that an agreement is thought to require, the more far-reaching the principle of good faith and the cognate obligations are likely to be, in two different senses: first, in a more extensive treaty the principle of good faith etc will be more farreaching simply because it applies to more objects; and, second, the application of the principles will involve differential depth of engagement by the parties with each other. If this approach is adopted, then the principle of 'good faith' etc in the WA, as applied in the Protocol, is likely to be considered more far-reaching than in Article 26 of the VCLT, Article 3 EEA or Article 3 TCA, but less far-reaching than Article 4(3) TEU. Much will depend, however, on the particular cases in which the issue arises.

\subsubsection{Good Faith etc and Sincere Co-operation as Lex Generalis}

There is also a significant difference between these Agreements in the extent to which they include detailed provisions on a range of issues which potentially overlap with the duties of good faith etc and sincere co-operation. So, for example, the fact that there are specific provisions in the Protocol regarding the requirement for domestic courts to refer issues of EU law to the CJEU means that the role that the duty of sincere co-operation plays in the EEA context in generating a duty to refer in certain circumstances is unnecessary. Lex specialis displaces lex generalis. The CJEU has been explicit on this point. TEU Article 4(3)'s predecessor provision, the Court held, is worded so generally that there can be no question of applying it autonomously when the situation concerned is governed by a specific provision of the Treaty .... ${ }^{12}$ Where there are gaps in the Protocol, ${ }^{13}$ however, the role of Article 5 may become critical. Where there are specific, detailed requirements,

12 Case C-18/93 Corsica Ferries [1994] ECR I-1783, para 18.

13 Klamert (n 4) 46 refers to the 'gap-filling' role of good faith. See also Vaughan Lowe's reference to the role of 'good faith' as 'interstitial': 'The Politics of Law-Making: Are the Methods and Character of Norm Creation Changing?' in M Byers (ed), The Role of Law in International Politics: Essays in International Relations and International Law (Oxford University Press 2000) 207. 
these will reduce the role that the more general concept of 'good faith' will need to play. The duty of 'good faith' is 'subsidiary to more specific Treaty provisions'. ${ }^{14}$

\subsubsection{Obligations Deriving from Article 5 WA}

Although the ends ('objectives') that each of the Agreements seeks to achieve differ (in some cases significantly, as we have seen), and the Article $5 \mathrm{WA}$ and Article $3 \mathrm{TCA}$ obligations are also situated in the context of differing substantive obligations in the various Agreements, the means by which these objectives and obligations may and should be met are mostly common to both of these Agreements. There are three basic obligations in Article $5 \mathrm{WA}$ and Article $3 \mathrm{TCA}$, applying to both the EU and the UK: (i) a positive obligation to assist each other in carrying out tasks which flow from the Agreement; (ii) a positive obligation to take all appropriate measures, whether general or particular, to ensure fulfilment of the obligations arising from the Agreement; and (iii) a negative obligation to refrain from any measures which could jeopardize the attainment of the objective of the Agreement.

With the exception of (i), which is not included in Article 3 EEA, these obligations mirror equivalently drafted obligations in Article 4(3) TEU, Article 3 EEA and Article 3 TCA. These all relate to the means by which the objectives of the relevant Agreements may and should be fulfilled. As a result, the interpretation of these common 'means' provisions should be seen as closely aligned. ${ }^{15}$ Following the approach adopted by Hreinsson in the EEA context, we may say that Article 5 WA will be construed in the same manner as the corresponding EU and EFTA provisions, 'so long as this interpretation is not irreconcilable with the provisions and characteristics' of the relevant Agreement. ${ }^{16}$ Unless any of the differences in drafting are material in a particular case, the CJEU's application of the concept of 'sincere co-operation' and the EFTA Court's interpretation of the 'loyalty' provision in Article 3 EFTA will both be highly relevant in understanding the meaning and scope of the obligations in Article 5 WA.

14 Klamert (n 4) 13.

15 In Case E-1/04 Fokus Bank ASA, [2004] EFTA Court Reports 11, the EFTA Court stated that Art 3 EEA mirrored Art 10 EC (now Art 4(3) TEU), para 41.

16 Hreinsson (n 5) 358. 


\subsubsection{Implications of Article 5 WA Obligations}

Several important principles deriving from the CJEU and the EFTA Court jurisprudence on 'sincere co-operation' apply to Article 5 WA:

(i) The obligations set out in Article 5 are legal obligations, not simply political commitments. ${ }^{17}$ 'Good faith' is sometimes said to be nonjusticiable and simply a declaration of political principle. This is inconsistent with the uninterrupted jurisprudence of analogous concepts by the CJEU and the EFTA Court, and Article 5 WA itself requires that this consistent jurisprudence should be followed in the interests of consistency. Obiter comments to the contrary by UK judges, however illustrious, should not be followed. ${ }^{18}$

(ii) The other obligations in Article 5 should not be seen through the international law lens of 'good faith' but should rather be seen in light of the interpretation of the analogous concepts in the EEA and the EU. This has significant implications, not only in distancing it from general international law understandings of 'good faith'. Some have interpreted a 'good faith' obligation as consisting of little beyond imposing an obligation to behave 'reasonably'. This understanding is common in diplomatic and political uses of the term and is reflected in some judicial interpretations of the term. This approach gives insufficient importance to the way in which the other obligations in Article 5 WA have come to possess the more technical meaning that this chapter now considers.

(iii) 'Good faith' and the other obligations in Article 5 WA may also differ significantly from apparently similar domestic law concepts. 'Good faith' is not, for example, simply the absence of 'bad faith', of a type that is common in UK public law. The positive obligations inherent in a duty of good faith go significantly beyond the concept of the absence of bad faith, as it is hoped this chapter demonstrates. That said, there are, as we have seen, some points of comparison in the use of similar concepts in national federal systems. ${ }^{19}$

17 In Case C-246/07, Commission v Sweden, the CJEU referred to the duty of sincere cooperation as giving rise to duties of co-operation that are legal duties - they are not just obligations regarding what is politically desirable.

${ }^{18}$ Such as those by Laws LJ in Ryanair Holdings $v$ Competition and Market Authority [2015] EWCA Civ 83, on which see Temple Lang, 'The Principle of Sincere Cooperation in EEA Law' (n 5).

19 Daniel Halberstam, 'Of Power and Responsibility: The Political Morality of Federal Systems' (2004) 90(3) Virginia Law Review 731 (comparative examination of the duty of co-operation in the EU, Germany and the United States). 
(iv) The obligation of 'good faith' and the other obligations in Article 5 WA are addressed to all the organs of the UK, including to UK courts for matters within their jurisdiction. ${ }^{20}$ The principle also applies to the institutions and bodies established by the WA and the Protocol, as well as to all the organs of the EU. The duty of good faith etc rests on mutual duties, and mutual respect, which bind not only the UK but also the Union institutions. This does not mean either that the 'good faith' obligation is symmetrical or that it depends on reciprocity.

Taken as a whole, the duty of 'good faith' will be seen to express the 'gravitational force' that the Protocol should have on all decisions taken by the UK and the EU that impact those objectives. ${ }^{21}$ The implications this will have for the UK and the EU have yet to be fully identified. That will be a work in progress for many years. However, as a first approximation, it will be useful to consider what the obligations in Article 5 WA are likely to require, using the three basic obligations identified above as the basic structure, considering them in reverse order.

Article 5 lists three obligations. First, the negative obligation to refrain from any measures which could jeopardize the attainment of the objective of the Agreement. As a result, the freedom of action in the future of both the EU and the UK is limited, 'excluding the right to legislate at will concerning the subject matter of the treaty'. ${ }^{22}$ At its most basic, Article 5 WA requires that the legal obligations of the Agreement must be upheld, echoing Article 26 VCLT, incorporating the principle of pacta sunt servanda. The obligations in Article $5 \mathrm{WA}$ can be seen in part as the equivalent to or an expression of these international law principles. ${ }^{23}$ The decision by the UK government to introduce legislation (the UK Internal Market Bill) that included provisions that explicitly empowered ministers to breach international obligations, including those under the Protocol, if that was necessary in order to protect the UK internal market, was a clear breach of this first element of the Article $5 \mathrm{WA}$ obligations. Whether a matter falls within the sovereign power of the EU or the UK does not alter the obligation,

${ }^{20}$ Klamert (n 4) 23 (on CJEU case law on the issue). See also EFTA Court decision, Case E-18/11 Irish Bank Resolution Corporation v Kaupthing Bank [2012] EFTA Court Reports 592, paras 58 and 123.

${ }^{21}$ The term 'gravitational force' is that of Klamert (n 4) 20, referring to Article 3 TEU.

${ }^{22}$ North Atlantic Coast Fisheries Case (Great Britain v United States of America) (Award) [1910] XI RIAA 169, para 188 (emphasis added).

${ }^{23}$ Klamert (n 4) 41. 
therefore, that, in situations covered by the WA and the Protocol, EU and UK rules must comply with these Agreements.

Second, Article 5 WA imposes the positive obligation to take all appropriate measures, whether general or particular, to ensure fulfilment of the obligations arising from the Agreement. This applies in particular to the implementation and enforcement of these obligations, including regarding the provision of national remedies, and respect for the allocation of competences in the Protocol. Several examples may be identified from other chapters: regarding the scope of 'direct effect', as discussed in Chapter 3, in which the duty of good faith tips the balance in favour of a generous interpretation; regarding the availability of damages remedies for failure by the UK to track replacement directives, as discussed in Chapter 12, in which the duty of good faith will be critical in deciding the scope of state liability; ${ }^{24}$ regarding the debateable role of the Charter of Fundamental Rights (CFR), as discussed in Chapter 13, in which the duty of good faith is relevant in deciding when it should apply. Other examples may also be identified. The UK is required to ensure that directives which have been implemented and satisfy certain conditions prevail over conflicting national law. ${ }^{25}$ This aspect of the duty of 'good faith' requires respect for the principle of consistent interpretation, developed in EU law. ${ }^{26}$

The third obligation in Article 5 WA consists in a positive obligation on each party to assist the other in carrying out tasks which flow from this Agreement. This includes the duty, in certain circumstances, to negotiate with the other party, to inform the other party of relevant developments, and not to act unilaterally where this would lead to difficulties for the other party in the sphere of the Protocol. An exemplification of these principles can be seen in the inclusion of 'good faith' in Article 169(1) WA. ('The Union and the United Kingdom shall endeavour to resolve any dispute regarding the interpretation and application of the provisions of this Agreement by entering into consultations in the Joint Committee in good faith, with the aim of reaching a mutually agreed solution.') This third wing of the obligation goes beyond the duty to negotiate, however. In infringement proceedings, the UK would also be required to co-operate in any inquiry of the Commission and to supply it with all the necessary information, and

${ }^{24}$ Case E-9/97, Sveinsbjörnsdóttir, [1998] EFTA Court Reports 95, para 61.

25 Case E-15/12 Jan Anfinn Wahl [2013] EFTA Court Reports 534, para 54.

26 Case E-1/07 Criminal proceedings against $A$ [2007] EFTA Court Reports 246, para 39 and Joined Cases E-9/07 and E-10/07 L'Oreal Norge [2008] EFTA Court Reports 258, para 28. 
vice versa. ${ }^{27}$ The EFTA Court has decided that the EFTA Surveillance Authority was under a duty in a state aid case not only to respect the right of the state to be heard but also to co-operate sincerely with the latter in that procedure. ${ }^{28}$

An application of this third element of the Article 5 WA set of obligations is to be found in the Commission's letter to the UK objecting to the unilateral extension by the UK of grace periods, ${ }^{29}$ and supporting the commencement of legal action by the EU. It drew heavily on WA Article 5 's good faith provision. 'The UK', the Commission wrote, 'has resorted to this unilateral action without any discussion or consultation with the EU side in the bodies established by the Agreement. It has therefore acted in breach of the mutual trust and spirit of cooperation ....' The Commission identified two separate sets of legal complaints: (i) a violation of the substantive provisions of the Protocol, Article 5(3) and (4) of the Protocol on Ireland-Northern Ireland, read in conjunction with relevant Union law listed in Annex 2; and, separately, (ii) a violation of the duty of good faith provided by Article 5 WA. The Commission required the UK to enter into consultations in the Joint Committee under Article 169 WA, with the aim of reaching a mutually agreed solution; failure to do so would lead to the triggering by the $\mathrm{EU}$ of the dispute settlement procedure under WA Title III of Part Six.

\section{4 'Sincere Co-operation' in Article 5 WA}

What are we to make of the proviso in Article 5 WA that the obligations we have just examined are 'without prejudice to the application of Union law pursuant to this Agreement, in particular the principle of sincere cooperation'? There appear to be three main implications of this provision. First, the duties that arise from Article 5 cannot be used to limit the scope or application of the principle of sincere co-operation in applying Union law (for example vis-à-vis a member state) that continues to apply to the EU under Article 4(3) TEU. This proviso would prevent the UK from arguing that an obligation on the EU under Article 4(3) TEU was trumped by Article 5 WA.

Second, the proviso is not drafted in such a way that it applies only to the EU institutions. At this point, we need to tread with care. Since the UK has left the EU, the Article 4(3) TEU duty of sincere co-operation

27 Klamert (n 4) 28.

28 Joined Cases E-5/04, E-6/04 and E-7/04 Fesil and Finnfjord [2005] EFTA Court Reports 117 , para 128.

29 See Chapter 5. 
clearly does not apply to the UK. There is no overarching duty on the UK to fulfil the aims of the Union in the exercise of its sovereign authority. However, there are various places in the WA and the Protocol where the UK has agreed to be bound to follow 'Union law', as several chapters of this book describe. ${ }^{30}$ Where that is the case, we need to bring in another critical common provision of the WA. We have seen that Article 4 WA provides that the '.. . the provisions of Union law made applicable by this Agreement shall produce in respect of and in the United Kingdom the same legal effects as those which they produce within the Union and its Member States'. This means that the general principles that continue to apply to the interpretation and application of Union law in the EU also apply to the interpretation and application of Union law if and when it applies in the UK by virtue of the WA and the Protocol. One of these general principles is the duty of sincere co-operation. If the duty of sincere co-operation in Article 4(3) TEU goes beyond the other obligations of the parties in Article 5 WA, then the interpretation of Union law, based on the duty of sincere co-operation, applies.

Arguably, there is a third implication. Article $4 \mathrm{WA}$ also provides that ' $t$ ] he provisions of this Agreement ... shall produce in respect of and in the United Kingdom the same legal effects as those which they produce within the Union and its Member States'. The implications of this provision, when read with Article $5 \mathrm{WA}$, are somewhat less clear. The Union must interpret and apply the WA in such a way that the aims of the Union are upheld. A maximalist interpretation would be that the UK is also required by Article $4 \mathrm{WA}$ to act in such a way in implementing and interpreting the WA as to fulfil the aims of the Union, but that seems a step too far. When Article 5 states that the obligations in Article 5 WA are 'without prejudice to the application of Union law pursuant to this Agreement, in particular the principle of sincere cooperation', this implies that the intention was that the duty of sincere co-operation under Article 4(3) TEU applies to the application of Union law only, not to the provisions of the WA itself, which do not constitute 'Union law'.

\subsection{Conclusions}

Early indications are, then, that Article $5 \mathrm{WA}$ is likely to play a significant role in future disputes between the UK and the EU over the application of

${ }^{30}$ Chapters 3, 5, 6, 9 and 10. 
the Protocol, not least because it helps to address a feature of EU-UK relations that seems unlikely to disappear quickly, namely the absence of trust. Article 5 WA stresses that, for the parties to the Protocol, it is about following not just the letter of that Agreement but its spirit. It means avoiding weak, implausible interpretations of that Agreement, and working through differences, not looking for reasons to get around the obligations. At the domestic level, however, in practice the primary role of Article 5 WA will be 'gap filling': where gaps in coverage are identified, or where anomalous results are likely to arise, or where the issue is simply not otherwise addressed in the text of the Protocol. Where there is no express provision to deal with situations, it is likely to be argued that because the Protocol is intended to meet a specified objective or contains a general obligation, Article 5 WA imposes a specific obligation to do or not to do something. The Northern Ireland legal system, in particular, is so multilayered ${ }^{31}$ that it would be unlikely for gaps not to be identified or for anomalous consequences not to be detected, and so Article 5 WA may become of critical importance.

31 Chapter 10. 
